\title{
Implementation of space vector modulation for two level three-phase inverter using dSPACE DS1104
}

\author{
Ismail Bouyakoub, Rachid Taleb, Hacene Mellah, Abdelaziz Zerglaine \\ Electrical Engineering Department, Hassiba Benbouali University, Algeria \\ Laboratoire Génie Electrique ET Energies Renouvelables (LGEER), Algeria
}

\section{Article Info \\ Article history: \\ Received Feb 7, 2020 \\ Revised Apr 5, 2020 \\ Accepted Apr 19, 2020}

\section{Keywords:}

AC motor drive dSPACE DS1104

Inverter

Pulse width modulation

Space vector modulation

\begin{abstract}
With increasing research and advancement in solid-state power electronic devices and microprocessors, various inverter control techniques employing pulse width modulation (PWM) are becoming popular especially in AC motor drive applications. The most commonly used techniques are Sinusoidal PWM (SPWM) and space vector modulation PWM (SVPWM). SVPWM is considered to be superior to the SPWM because of better DC bus utilization. In this paper, a real-time digital implementation of SVPWM algorithm for threephase two level inverter using dSPACE DS1104. The results obtained from the experimentation are closer to that of simulation, which confirms the validity of the implemented algorithm.
\end{abstract}

Copyright $@ 2020$ Institute of Advanced Engineering and Science. All rights reserved.

\section{Corresponding Author:}

Ismail Bouyakoub,

Electrical Engineering Department,

Hassiba Benbouali University of Chlef,

Laboratoire Génie Electrique et Energies Renouvelables (LGEER),

BP. 78C, Ouled Farès 02180, Chlef, Algeria.

Email: ism.bouyakoub@gmail.com

\author{
NOMENCLATURE \\ SVM : Space Vector Modulation \\ PWM : Pulse Width Modulation \\ SPWM : Sinusoidal Pulse Width Modulation \\ DSP : Digital Signal Processor \\ THD : Total Harmonic Distortion \\ r : : Modulation rates \\ $\mathrm{m} \quad$ : Modulation indices \\ R : Resistance \\ Uab : Line to line voltage
}

\section{INTRODUCTION}

Voltage inverters are an essential function of power electronics. They are present in the most varied fields of applications, the best known of which is undoubtedly that of the speed variation of AC machines. The strong evolution of this function was based, on the one hand, on the development of fully controllable, powerful, robust and fast semiconductor components, and on the other hand, on the almost universal use of so-called pulse width modulation (PWM). The dSPACE DS1104 controller enables the user to employ the MATLAB/Simulink tools for the development of control algorithms as well as simulation. With the availability of the library 
blocksets, it simplifies the programming task. The codes of the successfully simulated model can be linked and loaded directly to the dSPACE controller board for the real-time hardware operation [1-3].

The dSPACE is a rapid-prototyping tool which helps to create and test control algorithms developed in MATLAB/Simulink and implement them in actual hardware set-up. The dSPACE system in conjunction with MATLAB/Simulink forms a hardware-in-the-loop (HIL) simulation arrangement and is useful for realtime implementation. The DS 1104 R\&D Controller card and CP 1104 I/O board constitutes the hardware components of the dSPACE system. The DS 1104 R\&D Controller card is plugged into a PCI slot of a computer. The DS1104 is a high-speed digital controller used for real-time simulations. The system is based on a 603 Power PC floating-point processor running at $250 \mathrm{MHz}$ and for advanced I/O purposes, a slave-DSP subsystem based on TMS320F240 DSP microcontroller is used [4, 5].

\section{SPACE VECTOR FOR A TWO LEVEL INVERTER}

There is no single PWM method that is the best suited for all applications, and with advances in solid-state power electronic devices and microprocessors. Various pulse-width modulation (PWM) techniques have been developed for industrial applications. The most widely used PWM schemes for three-phase voltage source inverters are carrier based sinusoidal PWM [6-14] and space vector PWM (SVPWM) [15-23]. The output voltage per phase for a sinusoidal PWM based three phase converter is limited to 0.5Vdc (peak value) and the line-to-line RMS voltage is $0.612 \mathrm{Vdc}$. SVM is another direct digital PWM technique proposed in 1982. It has become a basic power processing technique in three-phase converters. SVM based converter can have a higher output voltage output at $0.707 \mathrm{Vdc}$ (Line-to-line, RMS). The classic SVM strategy, first proposed by Holtz and Van der Broeck. For Vector SVM, the vector represents the three sinusoidal output voltages that one desires. This vector is best approximated during each modulation interval by acting on the control of the three complementary switch sets. This vector PWM is not based on separate calculations for each arm of the inverter but on the determination of an approximated global control vector over a modulation period $T_{e}$. The circuit diagram of the considered model of the three-phase inverter is shown in Figure 1. The power stage consists of six switches. (that is to say $S_{1}, S_{2}, \ldots, S_{6}$ ) and a three-phase load correspondingly associated with a three-phase voltage $\left\{V_{a n}, V_{b n}, V_{c n}\right\} . V_{\alpha}$ and $V_{\beta}$, which are used to control the three-phase voltage of the inverter $[24,25]$.

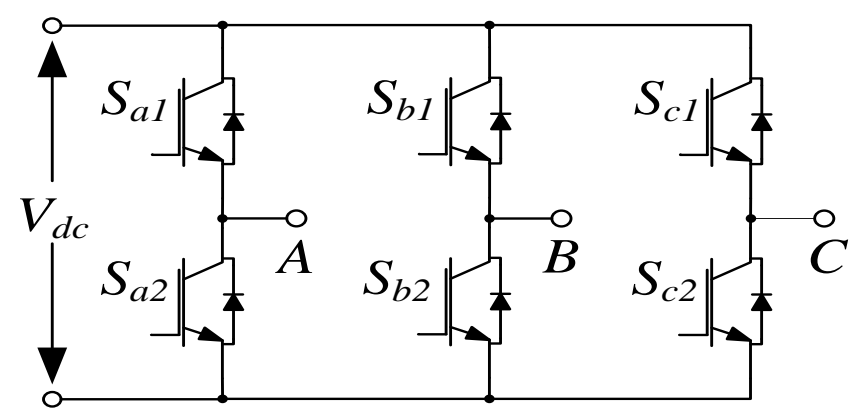

Figure 1. Circuit diagram of the SVPWM three-phase inverter

\subsection{Principle of vector modeling SVM}

The principle of vector modeling (SVM) consists in reconstructing the voltage vector $V_{a}$ a from eight voltage vectors. Each of these vectors corresponds to a combination of the state of the switches of a three-phase voltage inverter, it does not rely on separate calculations modulations by each arm of the inverter [15-20]. This technique follows the following principles:

a) $\quad V_{a}$ a Reference vector is calculated globally and approximated over a modulation period $T_{s}$.

b) All half-bridge switches have a state identical to the centers and ends of the period.

A combinatorial analysis of all the possible states of the switches makes it possible to calculate the voltage vector $\left(V_{\alpha}, V_{\beta}\right)$. So we draw a Table 1 , different states of the inverter. The vector $V_{\alpha}$ is approximated over the modulation period, by the generation of an average vector developed by the application of the available vectors. It consists in considering globally the three-phase system, and in applying to it a Concordia transform to be brought back into the plane $\left(V_{\alpha}, V_{\beta}\right)$. The three phase system of voltages to be generated for the current sampling time can then be represented as a single vector in this plane. In this model, if the ideal three-phase voltage we have: 


$$
\begin{aligned}
& V_{\text {aref }}=V_{m} \sin (2 * \pi * f * t) \\
& V_{b r \mathrm{e} f}=V_{m} \sin (2 * \pi * f * t-2 \pi / 3) \\
& V_{c r \mathrm{e} f}=V_{m} \sin (2 * \pi * f * t+2 \pi / 3) \\
& {\left[\begin{array}{l}
V_{a n} \\
V_{b n} \\
V_{c n}
\end{array}\right]=V d c / 3 *\left[\begin{array}{ccc}
2 & -1 & -1 \\
-1 & 2 & -1 \\
-1 & -1 & 2
\end{array}\right] *\left[\begin{array}{l}
S_{1} \\
S_{2} \\
S_{3}
\end{array}\right]} \\
& \left(\begin{array}{l}
V_{\alpha} \\
V_{\beta}
\end{array}\right)=\operatorname{P.}\left(\begin{array}{l}
V_{\text {aréf }} \\
V_{\text {bréf }} \\
V_{\text {créf }}
\end{array}\right)
\end{aligned}
$$

Table 1. Possible voltage at the output of the inverter

\begin{tabular}{ccccccccc}
\hline VECTOR & $\mathrm{S}_{1}$ & $\mathrm{~S}_{2}$ & $\mathrm{~S}_{3}$ & $V_{a n}$ & $V_{b n}$ & $V_{c n}$ & $V_{\alpha}$ & $V_{\beta}$ \\
\hline $\overrightarrow{V_{0}}$ & 0 & 0 & 0 & 0 & 0 & 0 & 0 & 0 \\
$\overrightarrow{V_{1}}$ & 1 & 0 & 0 & $2 V_{d c} / 3$ & $-V_{d c} / 3$ & $-V_{d c} / 3$ & $2 V_{d c} / 3$ & 0 \\
$\overrightarrow{V_{3}}$ & 0 & 1 & 0 & $-V_{d c} / 3$ & $2 V_{d c} / 3$ & $-V_{d c} / 3$ & $-V_{d c} / 3$ & $V_{d c} / \sqrt{3}$ \\
$\overrightarrow{V_{2}}$ & 1 & 1 & 0 & $V_{d c} / 3$ & $V_{d c} / 3$ & $-2 V_{d c} / 3$ & $V_{d c} / 3$ & $V_{d c} / \sqrt{3}$ \\
$\overrightarrow{V_{5}}$ & 0 & 0 & 1 & $-V_{d c} / 3$ & $-V_{d c} / 3$ & $2 V_{d c} / 3$ & $-V_{d c} / 3$ & $-V_{d c} / \sqrt{3}$ \\
$\overrightarrow{V_{6}}$ & 1 & 0 & 1 & $V_{d c} / 3$ & $-2 V_{d c} / 3$ & $V_{d c} / 3$ & $V_{d c} / 3$ & $-V_{d c} / \sqrt{3}$ \\
$\overrightarrow{V_{4}}$ & 0 & 1 & 1 & $-2 V_{d c} / 3$ & $V_{d c} / 3$ & $V_{d c} / 3$ & $-2 V_{d c} / 3$ & 0 \\
$\overrightarrow{V_{7}}$ & 1 & 1 & 1 & 0 & 0 & 0 & 0 & 0 \\
\hline
\end{tabular}

with $\mathrm{P}$ the transformation matrix developed by Concordia is given by the expression:

$$
\mathrm{P}=\sqrt{\frac{2}{3}}\left(\begin{array}{ccc}
1 & -\frac{1}{2} & -\frac{1}{2} \\
0 & \frac{\sqrt{3}}{2} & -\frac{\sqrt{3}}{2}
\end{array}\right)
$$

This control technique divides the $\alpha \beta$ resistance reference into six regions, as shown in Figure 2 . The voltage hexagon of the Figure 2 is the vector representation of the different combinations of the 3 magnitudes $\left(\mathrm{s}_{\mathrm{a}}, \mathrm{s}_{\mathrm{b}}, \mathrm{s}_{\mathrm{c}}\right)$ : non-zero vectors $\mathrm{v}_{1} \mathrm{a} \mathrm{v}_{6}\left(\mathrm{v}_{0}\right.$ et $\mathrm{v}_{7}$ being the null vectors $) \mathrm{v}_{0}:\left(\mathrm{s}_{\mathrm{a}}, \mathrm{s}_{\mathrm{b}}, \mathrm{s}_{\mathrm{c}}\right)=(0,0,0)$, $\mathrm{v}_{7}:\left(\mathrm{s}_{\mathrm{a}}, \mathrm{s}_{\mathrm{b}}, \mathrm{s}_{\mathrm{c}}\right)=(1,1,1)$.

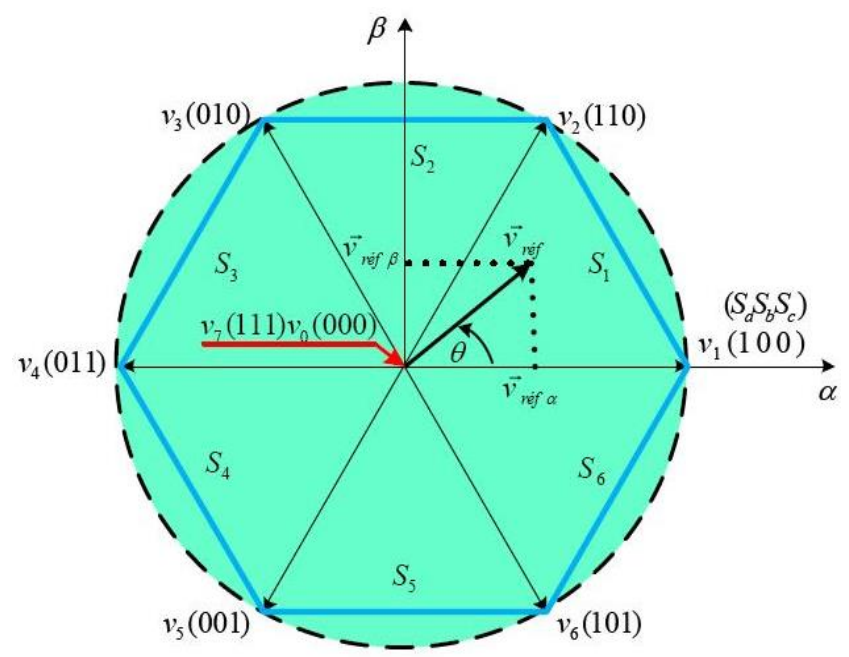

Figure 2. Hexagon of tension defined in the plane $\alpha-\beta$ 


\subsection{Detection of sectors by SVM algorithm}

The SVM algorithm makes it possible to locate a vector represented in the plane $\alpha-\beta$ based on these two data: Algebraic sign of the components $\alpha$ and $\beta$ of the vector; Amplitude of the $\beta$ component with respect to the amplitude of the component see Figure 3 [17-23].

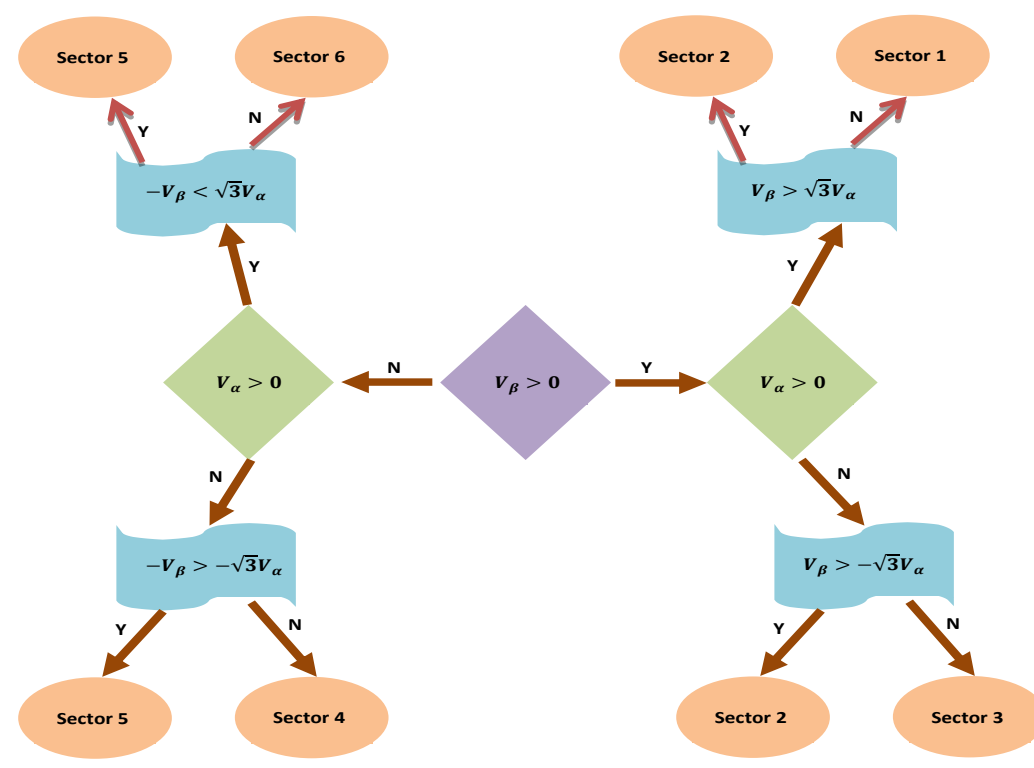

Figure 3. Detection of sectors by the SVM algorithm

\subsection{Generation of PWM}

A reference vector $V_{\text {ref }}$ is considered rotating in the concentric circle of the voltage hexagon, as shown in Figure 4(a) [18-22]. with:

$$
\begin{aligned}
& \mathrm{V}_{\mathrm{s}}=\left\{\begin{array}{c}
\mathrm{V}_{\mathrm{sk}}+\mathrm{V}_{\mathrm{sk}+1} \\
\frac{\mathrm{T}_{\mathrm{k}}}{\mathrm{T}_{\mathrm{s}}} \cdot \mathrm{V}_{\mathrm{k}}+\frac{\mathrm{T}_{\mathrm{k}+1}}{\mathrm{~T}_{\mathrm{s}}} \cdot \mathrm{V}_{\mathrm{k}+1}
\end{array}\right. \\
& T_{0}=\left(T_{S}-T_{1}-T_{2}\right) / 4
\end{aligned}
$$

Case of zone 1: This situation is shown in Figure 4(b).

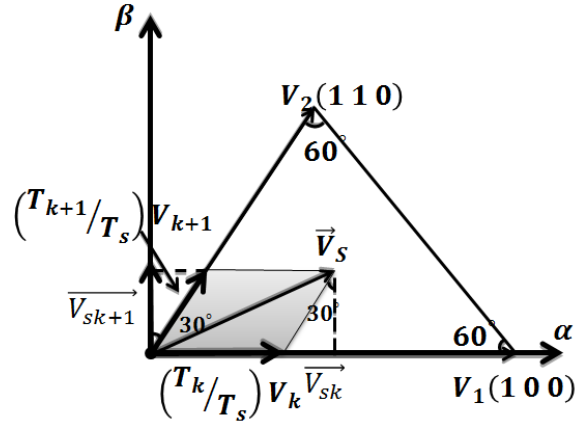

(a)

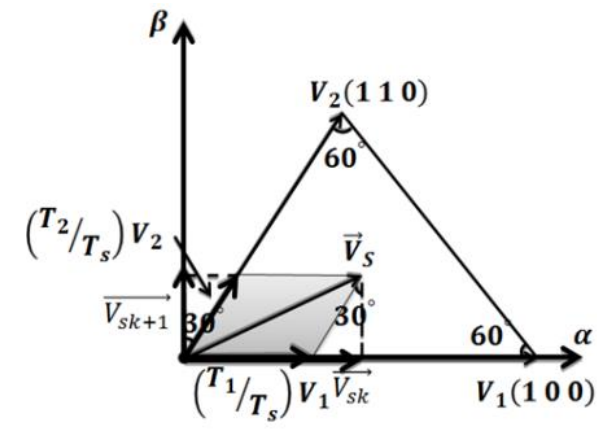

(b)

Figure 4. a) Rotation of the reference vector in the hexagon, b) case of zone 1

In this case:

Implementation of space vector modulation for two level three-phase inverter ... (Ismail Bouyakoub) 


$$
\begin{aligned}
& V_{s}=\left\{\begin{array}{c}
V_{s k}+V_{s k+1} \\
\frac{T_{1}}{T_{s}} V_{1}+\frac{T_{2}}{T_{s}} V_{2}
\end{array}\right. \\
& \left\{\begin{array}{c}
V_{s k}=\frac{T_{1}}{T_{s}} \cdot V_{1}+\frac{T_{2}}{T_{s}} \cdot V_{2} \sin \left(30^{\circ}\right) \\
V_{s k+1}=\frac{T_{2}}{T_{s}} \cdot V_{2} \cos \left(30^{\circ}\right)
\end{array}\right. \\
& \mathrm{V}_{2} \text { and } \mathrm{V}_{1}=\sqrt{2 / 3} \mathrm{~V}_{\mathrm{dc}}
\end{aligned}
$$

gets:

$$
\left\{\begin{array}{c}
T_{1}=T_{S} \frac{\sqrt{6} V_{s k}-\sqrt{2} V_{s k+1}}{2 V_{d c}} \\
T_{2}=T_{S} \sqrt{2} \frac{V_{s k+1}}{V_{d c}}
\end{array}\right.
$$

The pulse during a sampling period $T_{S}$ is presented in the timing diagram of Figure 5 (case of the three pulses of the three upper switches).

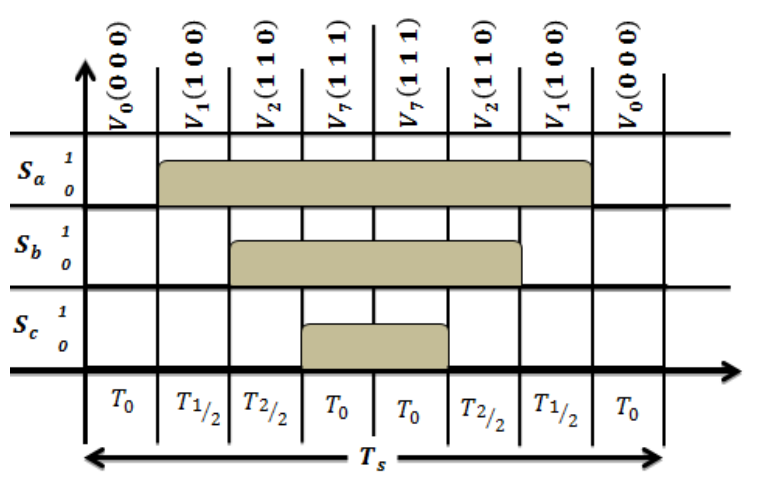

Figure 5. Impulse of zone 1

\subsection{Hardware implementation and experimental results}

Figures 6 and 7 represent the model of the tests. Figures 8 and 9 shows the line to line voltage of the three-phase two-level inverter controlled by SVM strategy for $V d c=250 \mathrm{~V}$, modulation index $=0.95$, load resistor $R=1 \mathrm{Ohm}$. The waveforms representing the experimental results are practically identical to the one obtained by simulation in [26]. To justify this superiority of SVM compared to sinusoidal pulse width modulation (SPWM) [26], we calculated the total harmonic distortion (TDH) for three modulation rates $r$ to different modulation indices $m$. The results obtained are given in Table 2 .

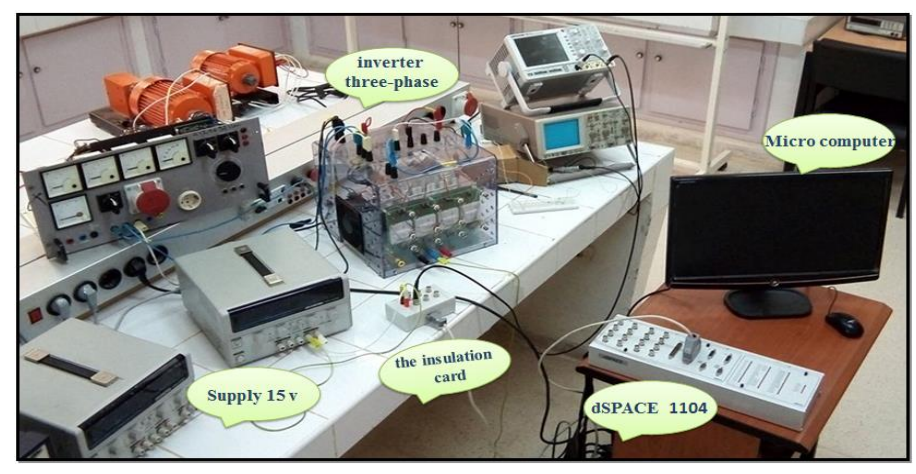

Figure 6. Presentation of the experimental setup 


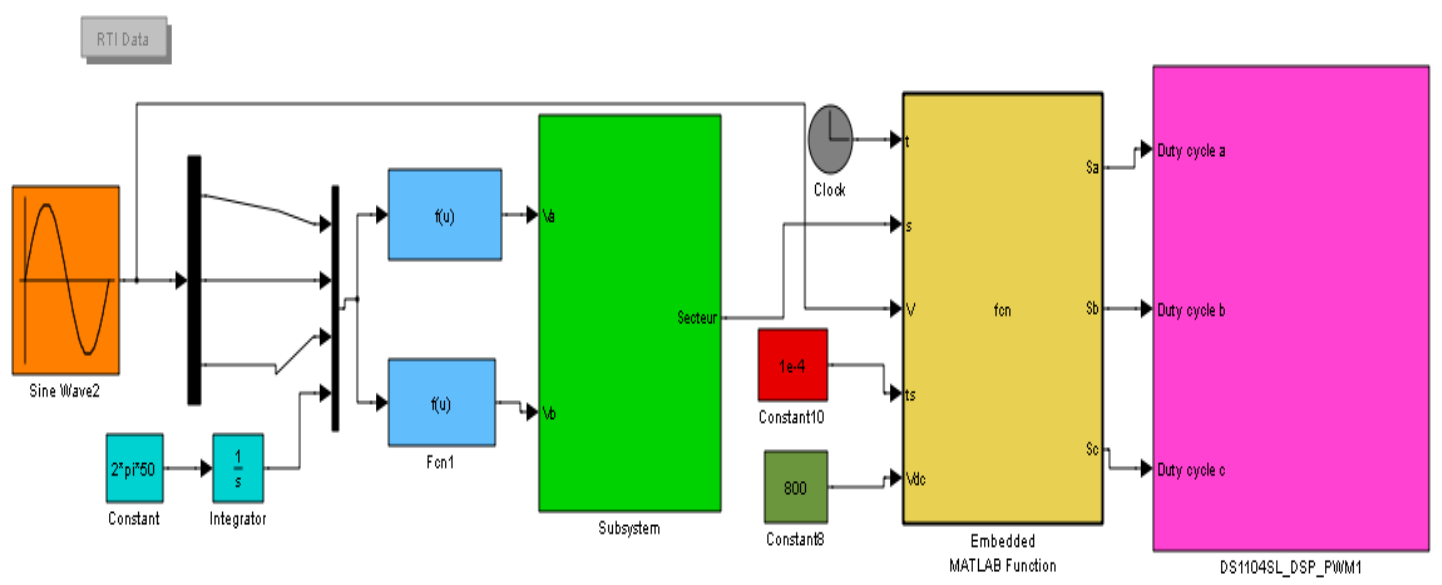

Figure 7. SVM control block

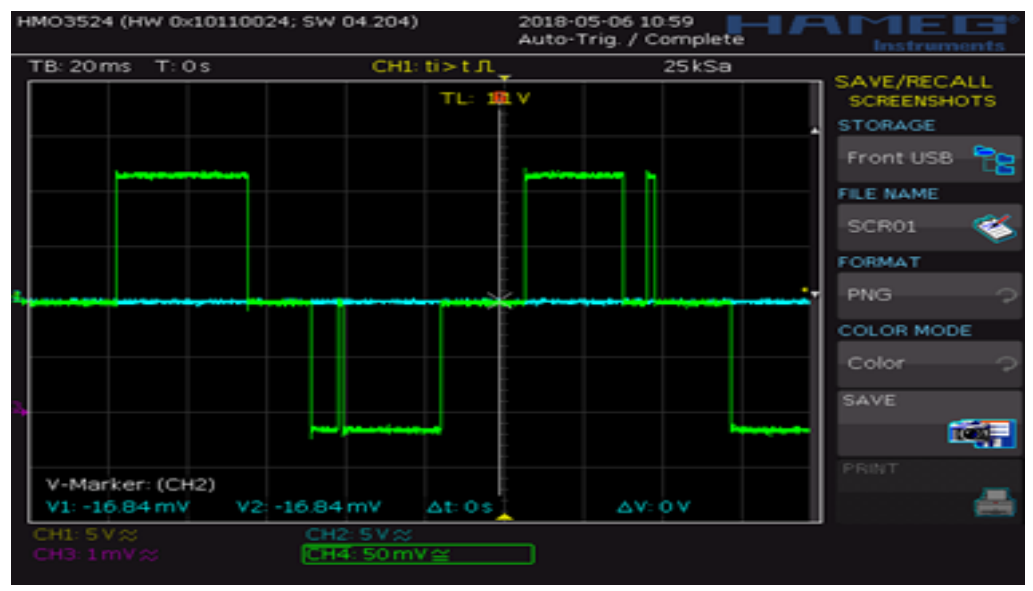

Figure 8. Line to line voltage $U_{a b}$ of the inverter (frequency $10 \mathrm{~Hz}$ )

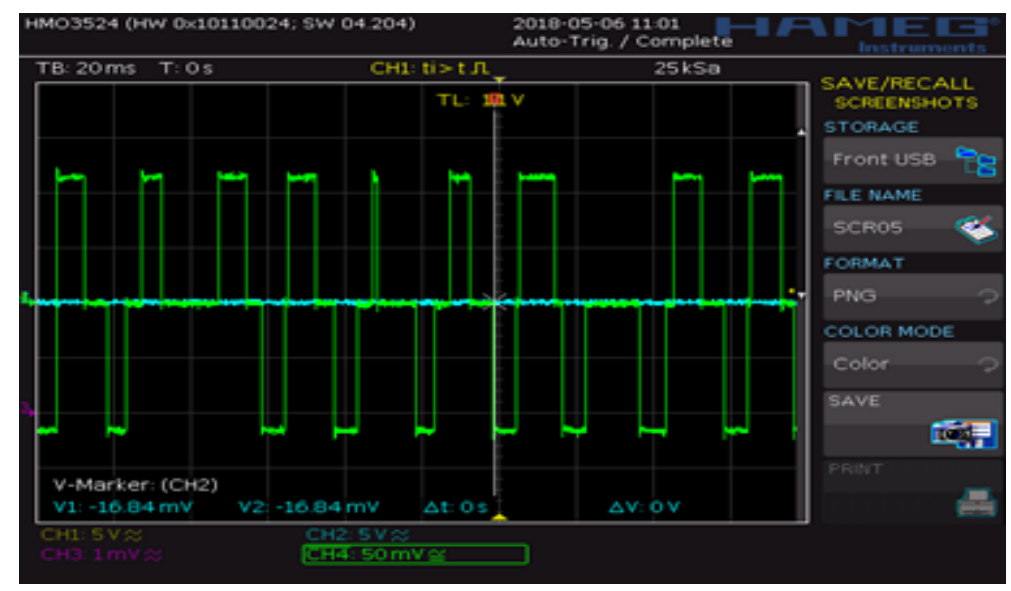

Figure 9. Line to line voltage $U_{a b}$ at the output of the inverter (frequency $50 \mathrm{~Hz}$ )

Table 2. THD comparison results

\begin{tabular}{ccccccc}
\hline$r$ & \multicolumn{9}{c}{0.9} & & & 1.15 & \\
\hline$m$ & 24 & 36 & 48 & 24 & 36 & 48 \\
THD (\%) of SPWM & 42.8 & 42.1 & 29.8 & --- & ---- & --- \\
THD (\%) of SVM & 28.1 & 26.9 & 19.4 & 34.2 & 32.4 & 23.3 \\
\hline
\end{tabular}




\section{CONCLUSION}

Experimental and simulation results reported in this paper confirm that the amplitude of line to line voltage is as high as DC bus voltage in SVM technique. It is concluded from the tabular data that inverter employing SVM has lower THD and higher fundamental component as compared to the inverter with SPWM.

\section{REFERENCES}

[1] Vinodhini R., Rajitha G., Kiran Kumar B. and Arun kumar G., "dSPACE based 12/24v closed loop boost converter for low power applications," 2014 International Conference on Computation of Power, Energy, Information and Communication (ICCPEIC), Chennai, pp. 213-217, 2014

[2] B. Lahfaoui, S. Zouggar, M. L. Elhafyani and A. Benslimane, "Modeling validation and MPPT technique of small wind PMSG turbines using DSPACE hardware," 2015 3rd International Renewable and Sustainable Energy Conference (IRSEC), Marrakech, pp. 1-6, 2015.

[3] P. H. To and D. Q. Phan, "A photovoltaic emulator using dSPACE controller with simple control method and fast response time," 2017 International Conference on System Science and Engineering (ICSSE), Ho Chi Minh City, pp. 718-723, 2017.

[4] V. Kumar Chinnaiyan, J. Jerome, J. Karpagam and S. Shiek Mohammed, "Design and implementation of high power DC-DC converter and speed control of DC motor using TMS320F240 DSP," 2006 India International Conference on Power Electronics, Chennai, pp. 388-392, 2006.

[5] R. C. Mateos and D. Libreros, "The application of TMS320F240 for voltage/frequency fuzzy control of a synchronous generator," ISIE'2000. Proceedings of the 2000 IEEE International Symposium on Industrial Electronics (Cat. No.00TH8543), Cholula, Puebla, Mexico, pp. 196-200 vol.1, 2000.

[6] Ibrahim Alhamrouni, N. Zainuddin, Mohamed Salem, Nadia H. A. Rahman, Lili Awalin, "Design of single phase inverter for photovoltaic application controlled with sinusoidal pulse width modulation," Indonesian Journal of Electrical Engineering and Computer Science (IJEECS), vol. 15, no. 2, pp. 620-630, 2019.

[7] N. Susheela, P. Satish Kumar, "Multicarrier SPWM Control Techniques for Three Phase Eleven Level Diode Clamped Multilevel Inverter and Hybrid Inverter with Reduced Number of Components," International Journal of Applied Power Engineering (IJAPE), vol. 7, no. 3, pp. 251-263, 2018.

[8] P. S. Sanjay, P. R. Tanaji and S. K. Patil, "Symmetrical Multilevel Cascaded H-Bridge Inverter Using Multicarrier SPWM Technique," 20183rd International Conference for Convergence in Technology (I2CT), Pune, pp. 1-4, 2018.

[9] K. A. Ogudo and J. W. Makhubele, "Comparative Analysis on Modulation Techniques For A Single Phase FullBridge Inverter on Hysteresis Current Control PWM, Sinusoidal PWM and Modified Sinusoidal PWM," 2019 International Conference on Advances in Big Data, Computing and Data Communication Systems (icABCD), Winterton, South Africa, pp. 1-7, 2019.

[10] R. K. Antar, "Multilevel inverter with unequal and selected DC voltage sources using modified absolute sinusoidal PWM technique," 2018 1st International Scientific Conference of Engineering Sciences - 3rd Scientific Conference of Engineering Science (ISCES), Diyala, pp. 62-67, 2018.

[11] S. A. Azmi, A. A. Shukor and S. R. A. Rahim, "Performance Evaluation of Single-Phase H-Bridge Inverter Using Selective Harmonic Elimination and Sinusoidal PWM Techniques," 2018 IEEE 7th International Conference on Power and Energy (PECon), Kuala Lumpur, Malaysia, pp. 67-72, 2018.

[12] A. Shamsul Rahimi A. Subki, Mohd Zaidi Mohd Tumari, Wan Norhisyam Abd Rashid, Aiman Zakwan Jidin, Ahmad Nizammuddin Muhammad Mustafa, "Hardware implementation of single phase three-level cascaded hbridge multilevel inverter using sinusoidal pulse width modulation," International Journal of Power Electronics and Drive Systems (IJPEDS), vol. 10, no. 2, pp. 625-635, 2019.

[13] C. R. Balamurugan, R. Bensraj, "Analysis of Various Carriers Overlapping PWM Strategies for a Single Phase Ternary Multilevel Inverter," International Journal of Applied Power Engineering (IJAPE), vol. 7, no. 1, pp. 27-39, 2018.

[14] S. Kakar, S. M. Ayob, N. M. Nordin, M. S. Arif, A. Jusoh, N. D. Muhamad, "A novel single-phase PWM asymmetrical multilevel inverter with number of semiconductor switches reduction," International Journal of Power Electronics and Drive Systems (IJPEDS), vol. 10, no. 3, pp. 1133-1140, 2019.

[15] J. R. V, J. B. Kummari and S. Keerthipati, "Operation of Nine-Phase Induction Machine under Single-Phase OpenWinding Fault Condition using Dodecagonal SVPWM and Hexagonal SVPWM," IECON 2019-45th Annual Conference of the IEEE Industrial Electronics Society, Lisbon, Portugal, pp. 3231-3236, 2019.

[16] D. Zhang, B. Xu, H. Yang and P. Zhu, "Simulation analysis of SVPWM based on seven-phase permanent magnet synchronous motor," 2017 International Conference on Control, Automation and Information Sciences (ICCAIS), Chiang, pp. 251-256, 2017.

[17] H. Chen et al., "A Novel Hybrid SVPWM Modulation Algorithm for Five Level Active Neutral-Point-Clamped Converter," 2019 IEEE Applied Power Electronics Conference and Exposition (APEC), Anaheim, CA, USA, pp. 2494-2498, 2019.

[18] G. Vivek, J. Biswas, A. K. Muthavarapu, M. D. Nair and M. Barai, "Optimised Design and Implementation of SVPWM Switching sequences for Five level VSI," 2018 IEEE International Conference on Power Electronics, Drives and Energy Systems (PEDES), Chennai, India, pp. 1-6, 2018.

[19] V. S. Niravadya, C. A. Sam and E. R. Samuel, "Photovoltaic Pumping System using SVPWM based Induction Motor Drive with a High Gain Converter," 2018 Second International Conference on Inventive Communication and Computational Technologies (ICICCT), Coimbatore, pp. 1909-1914, 2018. 
[20] Habib Benbouhenni, "A comparison study between fuzzy PWM and SVM inverter in NSMC control of stator active and reactive power control of a DFIG based wind turbine systems," International Journal of Applied Power Engineering (IJAPE), vol. 8, no. 1, pp. 78-92, 2019.

[21] K. Selvakumar, R. Palanisamy, Arul Rayappan Stalin, P. Gopi, P. Ponselvin, K. Saravanan, "Simulation of 3-phase matrix converter using space vector modulation," International Journal of Electrical and Computer Engineering (IJECE), vol. 9, no. 2, pp. 917-925, 2019.

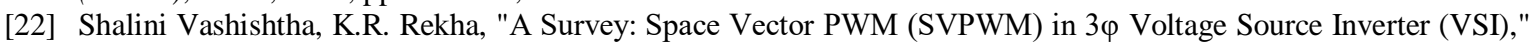
International Journal of Electrical and Computer Engineering (IJECE), vol. 8, no. 1, pp. 11-18, 2018.

[23] B. Sirisha, P. Satishkumar, "Simplified Space Vector Pulse Width Modulation based on Switching Schemes with Reduced Switching Frequency and Harmonics for Five Level Cascaded H-Bridge Inverter," International Journal of Electrical and Computer Engineering (IJECE), vol. 8, no. 5, pp. 3417-3426, 2018.

[24] Z. Miletic, W. Tremmel, R. Bründlinger, J. Stöckl and B. Bletterie, "Optimal control of three-phase PV inverter under Grid voltage unbalance," 2019 21st European Conference on Power Electronics and Applications (EPE '19 ECCE Europe), Genova, Italy, pp. P.1-P.11, 2019.

[25] D. C. Pham, "Modeling and simulation of two level three-phase voltage source inverter with voltage drop," 2017 Seventh International Conference on Information Science and Technology (ICIST), Da Nang, pp. 317-322, 2017.

[26] R. Taleb, A. Meroufel, A. Mellakhi, R. Dahmane, A. Cherid, "Etude comparative des performances de la commande triangulo-sinusoïdale et la commande vectorielle d'un onduleur à deux niveaux," ler Séminaire National sur le Génie Electrique Appliqué aux Energies Renouvelables (GEAER'10), Hassiba Benbouali University of Chlef, 2010. 